\title{
Human papilloma virus: global research architecture assessed by density-equalizing mapping
}

\author{
Dörthe Brüggmann ${ }^{1,2}$, Luise Kayser², Jenny Jaque ${ }^{1}$, Matthias Bundschuh², Doris \\ Klingelhöfer ${ }^{2}$ and David A. Groneberg ${ }^{2}$ \\ ${ }^{1}$ Department of Obstetrics and Gynecology, Keck School of Medicine of USC, Los Angeles, CA 90033, USA \\ ${ }^{2}$ Department of Female Health and Preventive Medicine, Institute of Occupational Medicine, Social Medicine and Environmental \\ Medicine, Goethe-University, Frankfurt 60590, Germany \\ Correspondence to: Doris Klingelhöfer, email: klingelhoefer@med.uni-frankfurt.de \\ Keywords: HPV; human papilloma virus; publication; bibliometry; scientometry \\ Received: August 16, $2017 \quad$ Accepted: March 11, $2018 \quad$ Published: April 24, 2018 \\ Copyright: Brüggmann et al. This is an open-access article distributed under the terms of the Creative Commons Attribution \\ License 3.0 (CC BY 3.0), which permits unrestricted use, distribution, and reproduction in any medium, provided the original author \\ and source are credited.
}

\section{ABSTRACT}

Human papilloma virus (HPV) infection is linked to cervical cancer, which represents the world's fourth most common cancer in women. So far, no detailed map of the worldwide HPV research architecture has been constructed. Hence, this study focuses on the chronological development and geographical distribution of the global HPV-specific publications and evaluates citation-based parameters as well as socioeconomic features of the publishing countries.

In total, 29,330 HPV-related publications were identified. The US was the leading country with 12,270 publications. Only high-income-countries were found in the ranking of the fifteen most active countries with Germany, France, and Japan among the top five. Analysis of HPV research activity in relation to the economic strength demonstrated a lead position of Finland and Sweden with an average of 2248.78 and 1924.67 HPV-related publications per GDP in 1000 bn US-\$, respectively. The most active upper-middle-income country was Mexico (416.78 HPV-related publications per GDP in 1000 bn US-\$). India as lower-middle-income country reached a value of 279.78 HPV-related publications per GDP in 1000 bn US-\$. Collaboration analysis pointed to the US as the center of the 4517 international HPV collaborations.

The worldwide HPV-research landscape is dominated by North American and Western European countries. By contrast, a high prevalence of HPV-related cervical cancer is documented for low-income countries. Hence, HPV-related public health interventions and prevention research specifically tailored to these countries needs to be fostered by monetary support and international collaborations.

\section{BACKGROUND}

The Human papillomavirus (HPV) plays a major role in various fields of oncology [1-11]. It is a resistant, ubiquitous virus that survives in the environment without a host. A chronic infection with high-risk genotypes of HPV causes around $70 \%$ of all squamous cervical cancers. Also, the pathogenesis of anogenital and oropharyngeal cancers has been linked to HPV [12]. From a global viewpoint, HPV is responsible for about $4.5 \%(630,000)$ of all new cancer cases worldwide causing a problem predominately in developing countries [13]. But also in industrialized nations, HPV infections and associated malignancies constitute a relevant public health burden. In the United States of America (US), nearly 80 million people are estimated to have a prevalent HPV infection [14]. The American Cancer Society predicts for 2018 that 13,240 women will receive a diagnosis of cervical cancer; 4170 deaths will be linked to this malignancy (American Cancer Society Facts and Figures 2015). 
Since the identification of HPV and its characterization as oncogenic agent, the related field of biomedical research grew rapidly. Besides screening practices and possible treatments, scientists are focusing upon public health issues concerning the prevention of HPV-associated diseases. Particularly, vaccine research merits a high academic and commercial interest, which has created an additional booster for HPV-related research. Concerning vaccination strategies, two vaccines are commonly used around the world, a bivalent vaccine targeting HPV 16 and 18 genotypes and a quadrivalent vaccine against HPV types 6, 11, 16, and $18[12,15$, 16]. Clinical trials demonstrated that three vaccine doses provide up to $100 \%$ protection against a cervical infection with HPV and related precancerous lesions in women aged 15-26 years with no prior exposure to the virus [12].

The global impact of HPV infections and their multi-layered clinical consequences have translated into an immediate call for action in the fields of public and global health. In this respect, the introduction of HPV vaccines was first only feasible in selected high-income countries due to high expenditures of vaccination costs [12]. Since prices dropped from 2011 onwards, some middle-income countries implemented HPV vaccination programs in their health systems [12]. In 2012, finally, the GAVI Alliance realized funding of pilot HPV vaccine projects in low-income countries $[12,17,18]$. This initiative will hopefully translate into widespread policy changes in underserved countries. Here, primary prevention is the key to effectively lower the population burden related to cervical cancer death because access to screening and treatment is extremely limited for local women.

Despite the enormous significance of HPV, its related conditions and their prevention, no systematic evaluation has been done yet to detail the global architecture of the worldwide scientific output associated with HPV. Efforts are lacking to understand developments in the related literature that can be utilized to plan future research activities or funding strategies according to identified shortcomings. Therefore, the NewQIS ("New Quality and Quantity Indices in Science") project platform [19] decided to analyze this respective field of medicine. As primary aim of this study, a picture of the global HPV research architecture was created, with regard to overall HPV research activity, its geographical and chronological trends, aspects of research quality and the economic background of the research.

\section{RESULTS}

\section{General parameters}

Between 1900 and 2009 a total of 29,330 publications (p) were identified. $96.3 \%$ of the HPVspecific items were published in English, $1.5 \%$ in German and $1.2 \%$ in French. 28,966 out of all HPV articles were authored between 1980 and 2009. There was a continuous increase in publication activities throughout the 1980s; the number of publications in 1989 was 13 times higher $(p=463)$ than in 1980. For 2009, we documented a total of 2439 HPV-specific publications (Figure 1A). Over time, the number of participating authors per item increased. While we found an average of 3.7 participating authors per HPV related paper in 1980, the average number of authors increased to nearly six in 2009.

\section{Country-specific analysis}

In the country-specific analyses, the United States (US) represented the country with the highest HPV research activity. US-American authors published a total of 12,270 publications. The US was followed by the United Kingdom (UK, $p=2644)$, Germany $(p=2463)$, France $(p=1670)$, Japan $(p=1316)$, Italy $(p=1292)$, Canada $(p=1076)$, the Netherlands $(p=1015)$ and Australia $(\mathrm{p}=789)$. DEMP analysis demonstrated a corresponding distortion of the world map with a focus on North America and Western Europe (Figure 1B).

The total citation number analysis listed the US also on position 1 (Figure 2A). The nation was followed by the UK and Germany with over 50,000 citations of HPVspecific publications each as well as France, Canada and the Netherlands with more than 25,000 citations. The analysis of the HPV-specific h-index for countries (termed the modified h-index) revealed a similar picture. We showed a leading position of the US, followed by the UK and Germany (Figure 2B). By contrast, when the citation number per research item (citation rate) were analyzed and a threshold of at least $30 \mathrm{HPV}$-specific publications per country was applied, the citation rate ranking was led by Chile, Costa Rica and Cuba and Uganda with more than 50 citations per HPV-specific publications. Also, scientists from Columbia and Peru authored publications with citation rates of over 40 and 30 citations per HPVspecific publication, respectively. When the threshold was increased to i.e. at least $100 \mathrm{HPV}$-specific publications per country, these countries disappeared from the ranking (Figure 2C).

\section{Socio-economic analysis}

When we related the gross domestic product as an indicator for total economic strength to the countries' HPV research activities, all of the fifteen top ranked countries could be identified as high-income countries according to the World Bank categories (Table 1). In this ranking, the two Scandinavian countries Finland and Sweden were ranked first and second with an average of 2254.48 and 1817.73 HPV-related publications per GDP in 1000 bn US-\$ (Socio-Economic HPV Index $1=\mathrm{SEI}_{1}$ ), respectively. They were followed by the Netherlands $\left(\mathrm{SEI}_{1}=1183.08\right)$, and the UK $\left(\mathrm{SEI}_{1}=1116.97\right)$. The US were ranked $7^{\text {th }}$ with 
a $\mathrm{SEI}_{1}$ of 850.98 . In this calculation, the highest uppermiddle-income country was Mexico with 416.78 HPVrelated publications per GDP in 1000 bn US-\$. India as lower-middle-income country reached a value of 288.53 and China as an upper-middle-income country a value of 87.71 HPV-related publications per GDP in 1000 bn US-\$.

When the HPV-specific publications were related to the relative economic power indicator GDP per capita in 1000 US-\$ (Socio-Economic HPV Index $2=\mathrm{SEI}_{2}$ ), the US were ranked at the top position with a value of $\mathrm{SEI}_{2}=257.90$, followed by China $\left(\mathrm{SEI}_{2}=116.83\right)$, the UK with a value of $\mathrm{SEI}_{2}=106.72$, and Germany $\left(\mathrm{SEI}_{2}=81.38\right)$.
Looking at the HPV-related publications per number of inhabitants $\left(\mathrm{SEI}_{3}\right)$ the following order can be determined: Finland $\left(\mathrm{SEI}_{3}=106.20\right)$, Sweden $\left(\mathrm{SEI}_{3}=83.99\right)$, Nethrlands $\left(\mathrm{SEI}_{3}=61.40\right)$, Belgium $\left(\mathrm{SEI}_{3}=44.37\right)$, UK $\left(\mathrm{SEI}_{3}=42.46\right)$ and the US at rank $6\left(\mathrm{SEI}_{3}=40.00\right)$.

\section{HPV subject area analysis}

We could identify a total of 57 different subject categories assigned to HPV research. The leading subject category was the category "Oncology" with $7098 \mathrm{HPV}$ publications, which was not surprising. It was followed
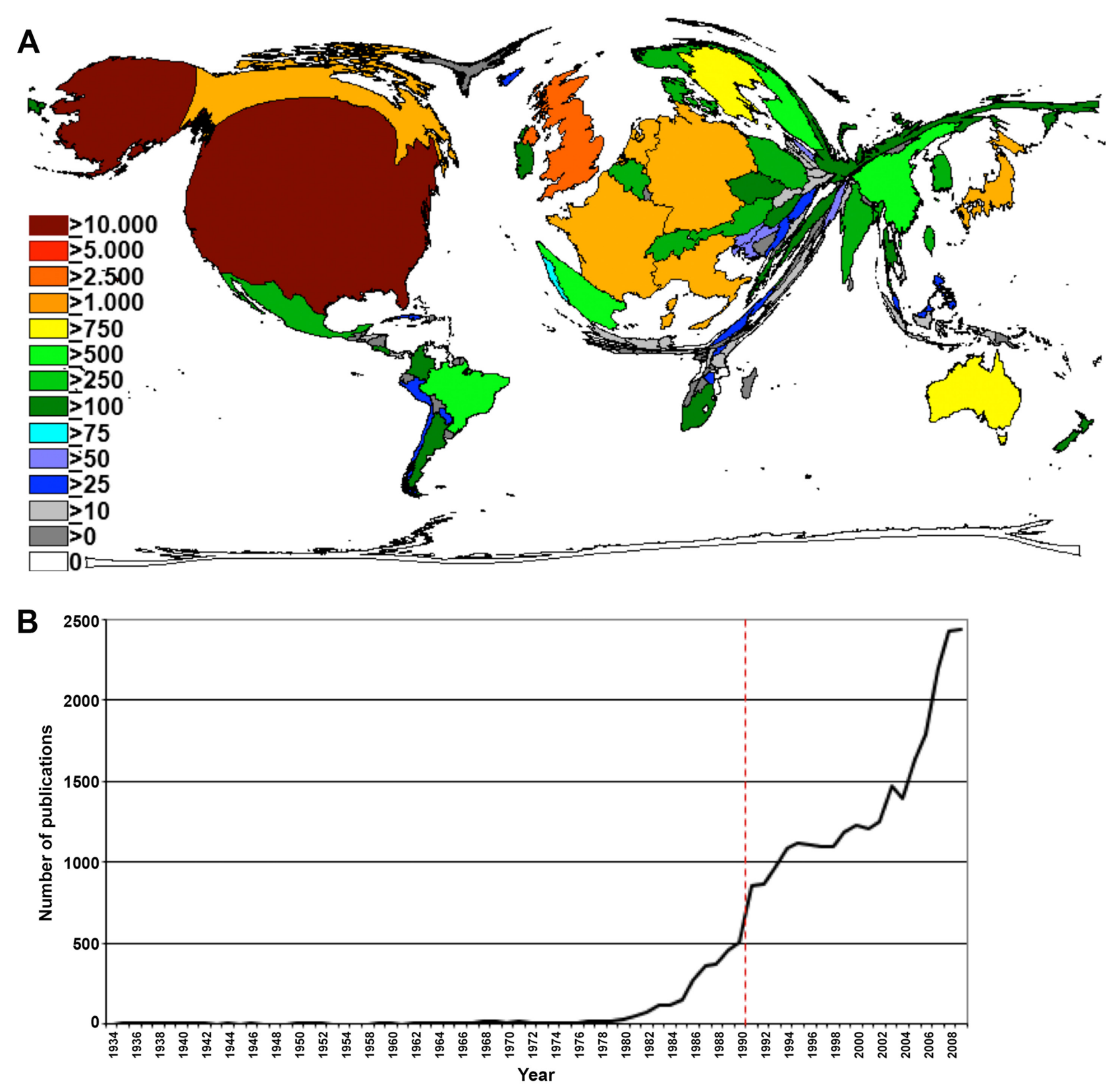

Figure 1: Research output. (A) Number of published items per year. (B) Density equalizing map of the global HPV research activity between 1900 and 2009. Colors and territorial sizes indicate numbers of HPV publications per country. 
by "Pathology" with $3661 \mathrm{HPV}$-related publications. We found "Obstetrics and Gynecology" and "Virology" at positions three and four with 3395 and 3352 HPV-related publications, respectively. "Public health" was at position 12 with about $1100 \mathrm{HPV}$-specific publications.

The proportion of the ten most frequent subject areas was also analyzed in a country-specific manner. Again, the most frequent subject category in all examined countries was "Oncology". The category
"Dermatology" was more frequently found in Germany, France and Japan in comparison to other countries. By contrast, the category "Obstetrics and Gynecology" had a high proportion in Brazil, Finland and South Korea (Figure 3). Numerous HPV-specific publications were assigned to two different subject categories indicating interdisciplinary approaches. The most common combination was "Oncology" with "Obstetrics and Gynecology” (Figure 4).
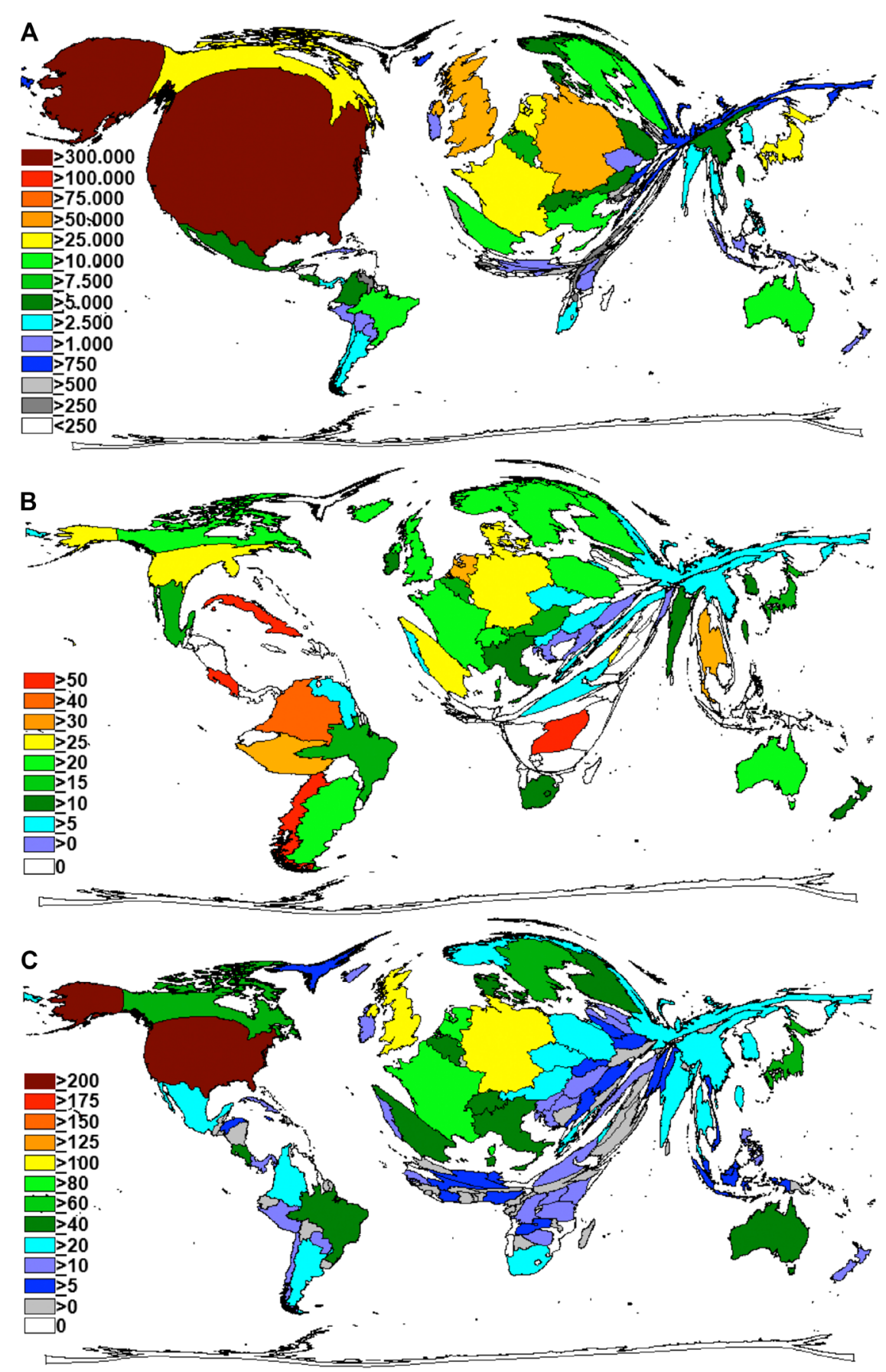

Figure 2: Density equalizing maps projections. (A) Total number of HPV-specific citations per country. (B) Levels of HPV-specific citation rates of countries (threshold 30 publications). (C) Levels of HPV-specific h-indices of countries. 
Table 1: Socio-economic analysis of HPV research of the ten most active countries

\begin{tabular}{lcccccccccc}
\hline Country & Publ. & GDP in & Publ./GDP & Rank & $\begin{array}{c}\text { GDP per Capita } \\
\text { in TUSD }\end{array}$ & $\begin{array}{c}\text { Publ./GDP per } \\
\text { Capita in TUSD }\end{array}$ & Rank & $\begin{array}{c}\text { Pop.in } \\
\text { mill. }\end{array}$ & $\begin{array}{c}\text { Publ./Pop. } \\
\text { in mill. }\end{array}$ & Rank \\
\hline Finland & 567 & 0,25 & 2254,48 & HI1 & 34,03 & 16,66 & HI9 & 5,34 & 106,20 & HI1 \\
Sweden & 781 & 0,43 & 1817,73 & HI2 & 357,16 & 2,19 & HI15 & 9,30 & 83,99 & HI2 \\
Netherlands & 1015 & 0,86 & 1183,08 & HI3 & 37,68 & 26,94 & HI6 & 16,53 & 61,40 & HI3 \\
UK & 2644 & 2,37 & 1116,97 & HI4 & 24,78 & 106,72 & HI2 & 62,28 & 42,46 & HI5 \\
Belgium & 479 & 0,48 & 988,54 & HI5 & 32,93 & 14,55 & HI10 & 10,80 & 44,37 & HI4 \\
Australia & 789 & 0,93 & 850,98 & HI6 & 63,90 & 12,35 & HI12 & 21,69 & 36,37 & HI9 \\
USA & 12270 & 14,42 & 850,98 & HI7 & 47,58 & 257,90 & HI1 & 306,77 & 40,00 & HI6 \\
Austria & 315 & 0,40 & 792,26 & HI8 & 34,65 & 9,09 & HI13 & 8,34 & 37,75 & HI8 \\
Canada & 1076 & 1,37 & 784,74 & HI9 & 47,95 & 22,44 & HI8 & 33,63 & 32,00 & HI10 \\
Germany & 2463 & 3,42 & 720,60 & HI10 & 30,27 & 81,38 & HI3 & 81,90 & 30,07 & HI11 \\
Taiwan & 474 & 0,71 & 664,14 & HI11 & 34,10 & 13,90 & HI11 & 22,97 & 20,63 & HI14 \\
France & 1670 & 2,69 & 619,94 & HI12 & 30,29 & 55,13 & HI4 & 64,71 & 25,81 & HI12 \\
Italy & 1292 & 2,19 & 591,26 & HI13 & 26,70 & 48,39 & HI5 & 59,10 & 21,86 & HI13 \\
Switzerland & 301 & 0,54 & 557,89 & HI14 & 76,03 & 3,96 & HI14 & 7,74 & 38,87 & HI7 \\
South Korea & 492 & 0,90 & 545,49 & HI15 & 24095,94 & 0,02 & HI17 & 49,31 & 9,98 & HI17 \\
Mexico & 373 & 0,89 & 416,78 & UMI1 & 101,13 & 3,69 & UMI3 & 115,51 & 3,23 & UMI1 \\
Spain & 569 & 1,50 & 379,57 & HI16 & 23,31 & 24,41 & HI7 & 46,36 & 12,27 & HI15 \\
Brazil & 613 & 1,67 & 367,72 & UMI2 & 8,21 & 74,63 & UMI2 & 194,90 & 3,15 & UMI2 \\
India & 382 & 1,32 & 288,53 & LMI1 & 61,19 & 6,24 & LMI1 1214,27 & 0,31 & LMI1 \\
Japan & 1316 & 5,23 & 251,56 & HMI17 & 3750,35 & 0,35 & HI16 & 128,05 & 10,28 & HI16 \\
China* & 701 & 7,99 & 87,71 & UMI3 & 6,00 & 116,83 & UMI1 1338,61 & 0,52 & UMI3 \\
\hline
\end{tabular}

* aus World Factbook.

$\mathrm{T}=$ Thousand.

Publ. = Publications.

Pop. $=$ Population

Sources for GDP (Current Prices in 1000 bn US Dollars) and GDP per capita (Current Prices in 1000 US Dollars) in 2009: World Bank (China/Taiwan figures are taken from the World Factbook, Population numbers in 2009, GDP and GDP per Capita in 2008. HI, high- income country, UMI, upper-middle-income country, LMI, lower-middle-income country according to the World Bank categories. Threshold level of at least $300 \mathrm{HPV}$-related publications.

\section{International HPV collaborations}

In our investigation of countries participating in collaborative HPV research, we identified the US again in the leading position among all 158 analyzed countries. In total, US-American authors dedicated to HPV research produced 4517 collaborative items. This equates a proportion of $15.4 \%$ of all HPV specific publications. The US was placed at the center of numerous collaborations established with nearly every other productive country. The highest level of bilateral HPV collaborations was present between the US and Germany with 332 collaborative publications (p), followed by prolific cooperations between the US and Canada $(\mathrm{p}=316)$, the US and the UK $(\mathrm{p}=266)$ as well as US and France $(\mathrm{p}=227)$ (Figure 5).

\section{DISCUSSION}

The present study is the first in-depth analysis to depict the global HPV-related research architecture. It covers a period of 110 years until the Nobel prize was awarded in 2008 for the identification of HPV as a causative agent for cervical cancer. Worldwide, cervical cancer and maternal mortality each result in about 
250,000 deaths per year. Also, cervical cancer causes tens of thousands of premature deaths per year in women from the most disadvantaged socioeconomic groups [12, 20]. Therefore, HPV constitutes a major global health problem. Until the development of vaccination strategies, approaches for cervical cancer control were extremely complex and expensive. Even in the current situation - with readily available HPV vaccines - cervical cancer control is a huge challenge particularly in developing nations where the disease is most prevalent [12]. To address this issue, the present study did not only cover high-income countries but focused also on middle and low-income countries. Using our validated approach, we further investigated the particular relationship between global health and economics. As hypothesized, we could detect only little research activities in most of the countries with lower economic capabilities, which served as a proxy measure for Research and Development expenditures. In this respect, cervical cancer shows a strong association with the level of development; prevalence rates were at least four-fold higher in countries ranked low in the Human Development Index (HDI) compared with those nations placed in a high category [21]. In low-resource settings, we found a considerable regional variation of cervical cancer rates with the highest numbers in Sub-Saharan
Africa (24\%), Eastern Europe (21\%) and Latin America $(16 \%)[22,23]$. A strikingly high prevalence was also reported for Eastern Africa and the Caribbean, where rates exceed $30 \%$ [21, 24]. For these particular regions with the greatest HPV-related burden for the female population, we could document only minimal scientific impact in the research community dedicated to HPV. This situation clearly needs to be improved. However, it does not seem realistic for these countries that basic HPV research will ever be conducted here with great success - simply due to the missing infrastructure or local personal, political or cultural challenges. But systematic public health research in the field of HPV prevention should be a realistic aim in order to rise awareness and implement standardized preventive strategies in rural and urban areas, i.e. of SubSaharan Africa. For instance, efforts have to be dedicated to investigate local vaccine acceptability and acceptance based on specific cultural and religious believes as a basis for effective vaccination campaigns in the future. Overall, our study reveals that most low-resource nations do not show relevant research productivity of on the quantitative level (i.e. total research activity as measured by country publications output), on the (semi-) qualitative level (i.e. measured by citation indices) and in cooperation with other. Hence, right now we simply cannot see a realistic

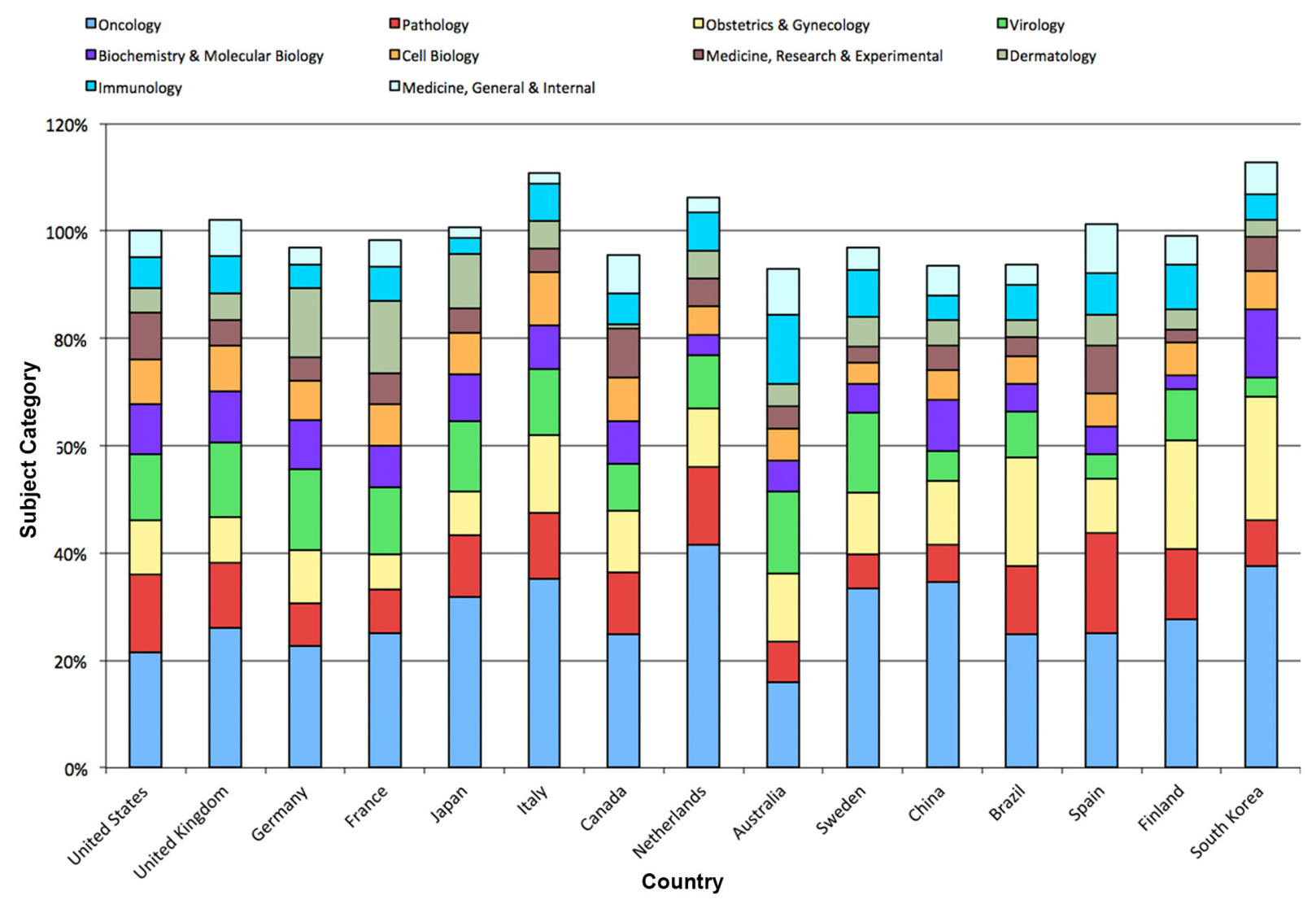

Figure 3: Subject area analysis of HPV research. Relative proportions of subject areas in most active countries. 
scientific perspective for these low-income countries when the present situation remains. The gap could be bridged if non-governmental and governmental funding institutions of high-income countries direct funding into preventive strategies of HPV-caused diseases initiated in these lowincome countries and also foster collaborative ties with institutions in high-income countries. By 2014, more than 57 countries included HPV vaccination strategies in their national health system programs, which is a promising step [12]. Since expansion of prevention programs to countries with the highest burden of disease is beginning [12], there is a hope that HPV related public health research will parallel this development in these countries.

Who might foster research in middle/low income countries within the area of HPV? Undoubtedly, nongovernmental organizations will have to step in, e.g. the Bill and Melinda Gates Foundation. As can be seen in the latest literature, the Gates organization already focused on HPV related conditions from a global health perspective. Currently, we found 13 publications listed in the PubMed database are related to the terms "Gates foundation" AND "HPV" [25-37]. The first report in 2005 is entitled: "Coming to terms with Vietnam: the Viet/ American Cervical Cancer Prevention Project" [25]. This Vietnamese-American Cervical Cancer Prevention Project had the objective to develop sustainable, cost-effective cervical cancer prevention services for women in Vietnam. The latest report estimated the value of point-of-care HPV testing in three low- and middle-income countries [37]. In its funding statement for the Alliance for Cervical Cancer Prevention, the Gates foundation awarded 50 million USD to conduct research and implement program projects in countries such as India, Mexico, Peru, Thailand, South Africa, Ecuador, Venezuela and Central America. Thereby, this funding initiative is a promising step to stimulate research in a global context that is desperately needed to address some of the shortcoming identified in our study.

In the country-specific analyses, the United States plays a dominant role within the research community dedicated to HPV. US-American authors publish the highest number of HPV-related articles, participate in the majority of international HPV collaborations, receive the

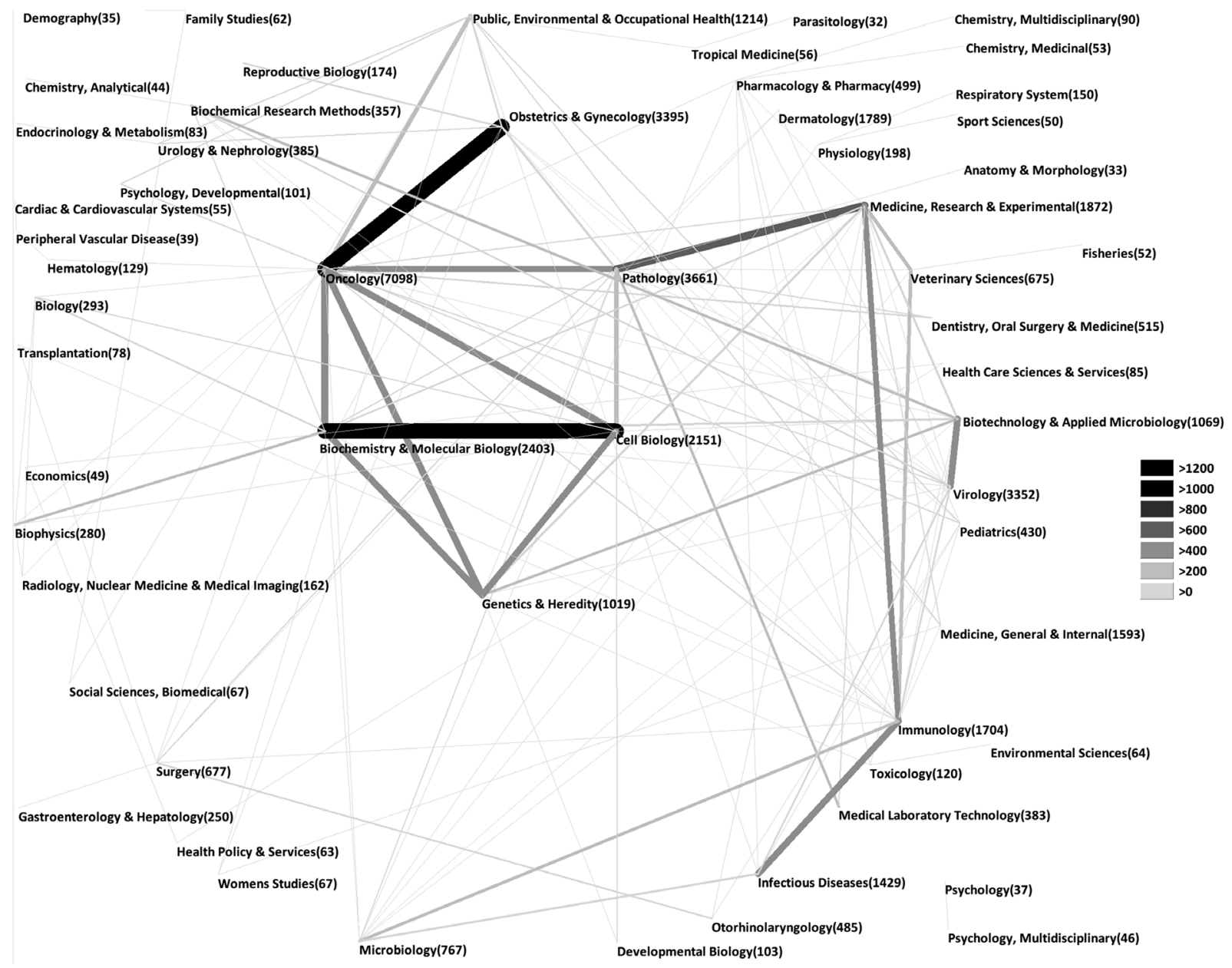

Figure 4: Combinations of subject areas in the field of HPV research. 
highest HPV-specific h-index and obtain most citations. Among the ten most productive players regarding HPV research worldwide, only North American and Western European countries are present besides Japan and Australia. We compared the HPV-specific research activity ranking to the global scientific productivity maps describing research on other infectious agents. In one study on yellow fever disease, a total of 5,053 yellow fever-associated publications were identified, which were published by authors from 79 countries in the period of over 110 years. Similar to the present findings on HPV, the US also had the highest publication activity. However, in striking contrast to the present findings, the country with the second highest research activity was the "non-highincome" country Brazil. This is not an unique finding since Brazil also had a high research activity in leishmaniasis research as two recent studies documented. The first analysis assessed global leishmaniasis research activities between 1957 and 2006 [38]. A second study covered the interval between 1945 until 2010 and confirmed the second position of Brazilian authors among leishmaniasis researchers worldwide [39]. Apart from the dominance of the US, another exceptional picture can be drawn when tuberculosis research is evaluated: Here, US-American authors issued 11,788 items of 58,319 TBC-specific publications. The US was followed by the UK ( $p=4202)$, India $(p=3456)$, France $(p=2541)$, South Africa $(p=1840)$, Germany $(p=1747)$ and China $(p=1427)$ [40]. When a total of 51,418 influenza virus specific publications were analyzed using a similar approach [41], the ranking of most active countries lists the US $(p=19,194)$ at the top position, followed by the UK ( $\mathrm{p}=4614)$, Germany $(\mathrm{p}=2951)$ and Japan $(\mathrm{p}=2815)$. In bacterial meningitis research, the US leads global research activities with a number of 2698 bacterial meningitis-related publications, followed by the UK ( $=912)$, Germany $(p=749)$ and France $(\mathrm{p}=620)$ [42].

In contrast to leishmaniasis and yellow fever, which predominantly occur in low-income countries, HPV also affects women in high-income countries. Therefore, the

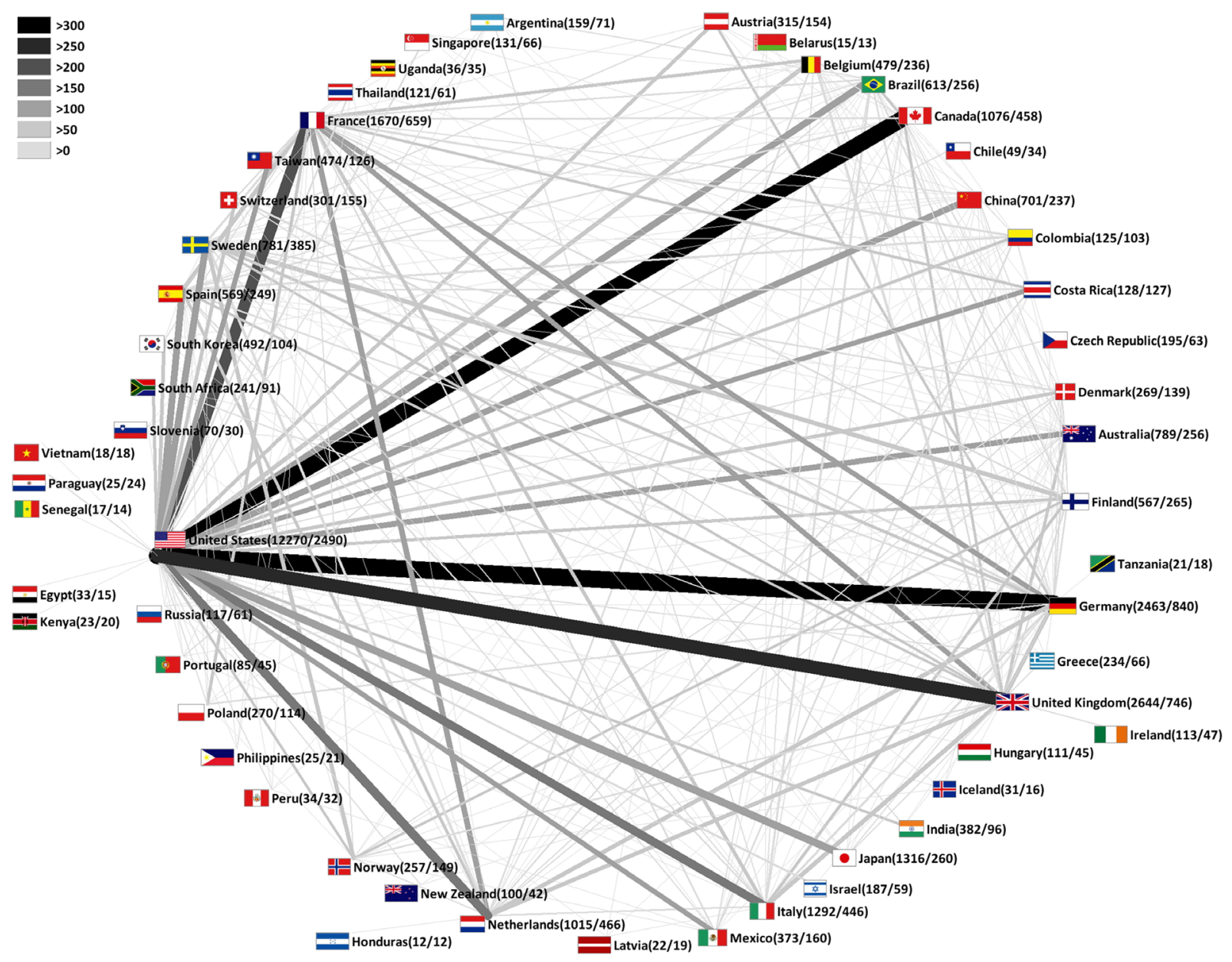

Figure 5: HPV research collaborations between countries. Greyscale and bar thickness indicate intensity of collaborations. First ciphers in brackets indicate total publication numbers. Second ciphers indicate number of collaborative publications. Threshold: 10 collaborations of a single country. 
present data on HPV should also be compared to other infectious agents that play a major role in high-income countries. In this respect, one study focused on the Hepatitis B virus (HBV) [43] which is currently reported to be the tenth leading cause of death worldwide. In this study, scientometric methods and large-scale data analysis were used to evaluate quality and quantity of HBV research in the period between 1971 and 2011. In total 49,166 items were published by authors from 250 countries. Similar to the present study on HPV, the US was the most active country with a total of $28 \%$ of all HBVrelated publications. It was followed by Germany, China, the UK, Japan, France, Italy and Taiwan, respectively. Apart from China, no other country in the top ten was listed as an upper middle-income country, revealing similarities to the present findings.

The present socio-economic assessment of global HPV research activities indicates a prominent role of Scandinavian countries when the total publication activity is related to the GDP. Furthermore, these nations often lead the ranking when qualitative research benchmarks are evaluated (i.e. the citation rates). This finding indicates that these nations produce high quality research very effectively. Overall, middle-income countries were generally ranked lower among the power players in HPV research. This finding did not change when HPV-specific research was related to socio-economic figures, e.g. regardless of the population numbers of these countries. By contrast, when the population size-sensible index GDP/capita is used in our calculations, countries with a high population size such as China, gain importance. They occupy an outstanding position in the ranking since their GDP per capita is relatively low. However, the predominance of US-American research in the field of HPV is still undisputed. Its leading position remained unchanged when research productivity was related to socio-economic figures. For example, the US was placed in the top position when research output was seen in context to the GDP per capita as demonstrated by a value of $\mathrm{SEI}_{2}=257.90$. China followed with a $\mathrm{SEI}_{2}$ of 116.83 . This finding once again underlines the highly productive US-American scientific community, which is remarkable since China lagged far behind despite its extremely low GDP per capita (China 6000 US-\$ GDP/capita versus US 47,580 US-\$ GDP/capita). The US-American success within the HPV research community in particular or generally in the scientific world can be attributed to the immense resources the country dedicates to Research and Development and to the well established scientific infrastructure and collaborations. For example, the Gross domestic spending on Research and Development totaled 2.74\% of its GDP in 2010 (https://data.oecd.org/rd/grossdomestic-spending-on-r-d.htm). Also, US-American researchers were on the forefront of collaborative efforts not only in the field of HPV research but also in many other biomedical fields, which accelerated the US-
American research productivity and the output of their partners.

\section{MATERIALS AND METHODS}

\section{NewQIS protocol}

To conduct this project, we used the previously described and established New Quality and Quantity Indices in Science (NewQIS) protocol aiming to analyze scientific productivity via standardized, objective and validated procedures $[44,45]$. NewQIS is based upon a combination of established scientometric and economic analysis techniques; the findings were visualized via density equalizing mapping projections as employed in earlier studies [46].

\section{Data source}

NewQIS uses the online database "Web of Science" (WoS, Thomson Scientific) [47, 48]. As an advantage, the database does not only provide data for the overall research activity analysis (publication entries) but also gives the opportunity for citation metrics in order to assess (semi)-qualitative aspects of HPV research.

\section{Search strategy}

The search terms "HPV", "human papilloma virus", and "human papillomavirus" were used to identify and assess the HPV-related research activity between 1900 and 2009. We chose to evaluate this respective time period to generate an encompassing search with valid results. As observed in our other studies, the effect of the "cited half life of publications" refers to a time period of the latest years, when a decline in citations is usually seen. This finding does not represent the true recognition the publications receive in the scientific community because the time span after publication is simply too short and the items had not enough time to be cited adequately. Also, a decline of citations can be seen due to "aging" of articles. Hence, we feel the limitation of the study until 2009 was justified so the overall results will not be blurred. Also, we expect that the Nobel prize award in December 2008 will have a ripple effect on the scientific community. Therefore, the stimulated productivity needs to be analyzed to a later point in time to ensure a proper evaluation.

We used the previously mentioned search terms to conduct an all encompassing TOPIC search that identified the terms of interest in title, abstract and author key word section and identified all document types related to HPV.

\section{Data analysis and categorization}

After retrieval of metadata of all HPV-related publications, bibliographic details were sorted and analyzed according to a number of criteria. These 
included the countries of origin, languages, document types, citations, cited references, year published and subject categories for all HPV-related publications. From these metadata, HPV research-specific modified country h-indices were calculated. This index was developed by Jorge Hirsch in 2005 for an assessment of the scientific quality of all items a specific author contributed to the field [49]. Here, we applied the concept to evaluate the output of single countries specifically regarding HPV research and therefore termed the parameter "modified h-index".

\section{Density equalizing mapping}

Density-equalizing mapping projections (DEMP) constitute a validated core technique to generate world maps that visualize geographical trends in HPV research. As described earlier [47, 50], after transfer of the bibliometric information to a data base and parameter analysis, DEMP were calculated according to the algorithm of Gastner and Newman [51], using the GeoVIZ toolkit [52]. Briefly described, the territories of the different publishing countries were separated from each other and resized in proportion to the selected criterion (i.e. country-specific h-index).

\section{Socio-economic analyses}

In order to assess the relative contributions of the single countries towards HPV research in regard to their financial abilities, the nations' gross domestic products (GDP) and their investments in research and development were related to their HPV research activities. Additionally, the population of the countries has been taken into account. The socio-economic numbers were obtained from the World Bank Database [53] and have references to the year 2009. Additionally, the categories of the World Bank have been chosen to define the different economic performances of the countries: Thus, the Gross National Income (GNI) per capita in low-income countries totals 1,005 USD (US-Dollar) or less. In lower-middle-income countries, the GNI per capita ranges from 1,006 to 3,955 USD, in upper-middle-income from 3,956 USD to 12,235 USD. High-income countries are defined by a GNI per capita of 12,236 USD and above. China's and Taiwan's figures has been taken from the CIA World Factbook (2008 = GDP/GDP per Capita; $2009=$ Population $)$.

\section{Analysis of collaborations}

To analyze HPV research collaborations from a global perspective, all affiliations of the HPV-specific publications were processed as earlier described for other diseases [54, 55]. In brief, if two authors or more, who were affiliated to different countries, contributed to one HPV-specific publication, we defined this relationship as a collaboration. To visualize these interactions for single pairs of countries, vectors were generated, which were proportional in shades of grey and width to the number of established bilateral HPV collaborations $[54,55]$.

\section{CONCLUSIONS}

In summary, this study is the first in depth analysis of the worldwide HPV research architecture. Using density-equalizing mapping techniques in combination with research quantity and quality indices and economic benchmarks, a global landscape of HPV research was illustrated. Our data illustrate a research activity, which largely follows the global economic situation. However, since HPV endangers wellbeing and health of women especially in low-income countries from an epidemiological perspective, these countries should be supported to participate in HPV research - predominantly in the sector of public health and prevention strategies as well as in collaborations with high-income countries.

\section{Abbreviations}

DEMP Density Equalizing Map Projections; GDP: Gross Domestic Product; HBV: Hepatitis B Virus; HDI: Human Development Index; HI: High-income country; HPV: Human Papilloma Virus; LMI: Lower-middle-income country; NewQIS: New Quality and Quantity Indices in Science; p: Publications; SEI : Socio-Economic HPV Index 2 (Publications/GDP in 1000 bn US-\$); SEI $_{2}$ : Socio-Economic HPV Index 2 (Publications/GDP per capita in 1000 US\$); SEI3: Socio-Economic HPV Index 3 (Publications/ Population Population in mill.); US: United States; UMI: Upper-middle-income country; WoS: Web of Science.

\section{Author contributions}

$\mathrm{DB}, \mathrm{LK}, \mathrm{JJ}, \mathrm{MB}, \mathrm{DK}$, and $\mathrm{DAG}$ have made substantial contributions to the conception and design of the study, acquisition of the data and interpretation. They have been involved in drafting and revising the manuscript. All authors have read and approved the final manuscript.

\section{DECLARATIONS}

\section{Ethics approval and consent to participate}

Not applicable.

\section{Consent to publish}

Not applicable.

\section{Availability of data and material}

The datasets used and/or analyzed during the current study available from the corresponding author on reasonable request. 


\section{ACKNOWLEDGMENTS}

We thank Christian Scutaru for the establishment of the analysis unit and helpful comments. This study is part of a $\mathrm{PhD}$ thesis project (LK).

\section{CONFLICTS OF INTEREST}

The authors declare that they have no conflict of interest.

\section{FUNDING}

This study was not funded externally.

\section{REFERENCES}

1. Abulizi G, Li H, Mijiti P, Abulimiti T, Cai J, Gao J, Meng D, Abula R, Abudereyimu T, Aizezi A, Qiao YL. Risk factors for human papillomavirus infection prevalent among Uyghur women from Xinjiang, China. Oncotarget. 2017; 8:97955-64. https://doi.org/10.18632/oncotarget.18901.

2. Chen X, Liu H, Wang Z, Wang S, Zhang T, Hu M, Qiao L, $\mathrm{Xu}$ X. Human papillomavirus 16L1-58L2 chimeric viruslike particles elicit durable neutralizing antibody responses against a broad-spectrum of human papillomavirus types. Oncotarget. 2017; 8:63333-44. https://doi.org/10.18632/ oncotarget. 19327.

3. Guo L, Liu S, Zhang S, Chen Q, Zhang M, Quan P, Sun $\mathrm{X}$. Human papillomavirus infection as a prognostic marker for lung adenocarcinoma: a systematic review and metaanalysis. Oncotarget. 2017; 8: 34507-15. https://doi. org/10.18632/oncotarget.15671.

4. Jung YS, Najy AJ, Huang W, Sethi S, Snyder M, Sakr W, Dyson G, Huttemann M, Lee I, Ali-Fehmi R, Franceschi S, Struijk L, Kim HE, et al. HPV-associated differential regulation of tumor metabolism in oropharyngeal head and neck cancer. Oncotarget. 2017; 8:51530-41. https://doi. org/10.18632/oncotarget.1788.

5. Li P, Tan Y, Zhu LX, Zhou LN, Zeng P, Liu Q, Chen MB, Tian Y. Prognostic value of HPV DNA status in cervical cancer before treatment: a systematic review and metaanalysis. Oncotarget. 2017; 8:66352-59. https://doi. org/10.18632/oncotarget.18558.

6. Lin M, Xue XY, Liang SZ, Li YX, Lv YY, He LH, Xu KC, Zhang LF, Chen JB, Niu LZ. MiR-187 overexpression inhibits cervical cancer progression by targeting HPV16 E6. Oncotarget. 2017; 8:62914-26. https://doi.org/10.18632/ oncotarget.17516.

7. Lorincz AT, Nathan M, Reuter C, Warman R, Thaha MA, Sheaff M, Vasiljevic N, Ahmad A, Cuzick J, Sasieni P. Methylation of HPV and a tumor suppressor gene reveals anal cancer and precursor lesions. Oncotarget. 2017; 8:50510-20. https://doi.org/10.18632/oncotarget.17984.
8. Saha SS, Chowdhury RR, Mondal NR, Roy S, Sengupta $\mathrm{S}$. Expression signatures of HOX cluster genes in cervical cancer pathogenesis: Impact of human papillomavirus type 16 oncoprotein E7. Oncotarget. 2017; 8: 36591-602. https:// doi.org/10.18632/oncotarget.16619.

9. Tian Y, Yuan Wu NY, Liou YL, Yeh CT, Cao L, Kang YN, Wang HJ, Li Y, Chu TY, Li W, Liu X, Zhang Y, Zhou H, Zhang Y. Utility of gene methylation analysis, cytological examination, and HPV-16/18 genotyping in triage of high-risk human papilloma virus-positive women. Oncotarget. 2017; 8:62274-85. https://doi.org/10.18632/ oncotarget.19459.

10. Wang L, Cai Y, Xiong Y, Du W, Cen D, Zhang C, Song Y, Zhu S, Xue X, Zhang L. DNA plasmid vaccine carrying Chlamydia trachomatis $(\mathrm{Ct})$ major outer membrane and human papillomavirus 16L2 proteins for anti-Ct infection. Oncotarget. 2017; 8: 33241-51. https://doi.org/10.18632/ oncotarget.16601.

11. Zhang C, Liu F, Pan Y, Deng Q, Li X, He Z, Liu M, Ning T, Guo C, Liang Y, Xu R, Zhang L, Cai H, Ke Y. Incidence and clearance of oral human papillomavirus infection: A population-based cohort study in rural China. Oncotarget. 2017; 8:59831-44. https://doi.org/10.18632/ oncotarget. 16306.

12. Herrero R, Gonzalez P, Markowitz LE. Present status of human papillomavirus vaccine development and implementation. Lancet Oncol. 2015; 16: e206-e16. https:// doi.org/10.1016/s1470-2045(14)70481-4.

13. Serrano B, Brotons M, Bosch FX, Bruni L. Epidemiology and burden of HPV-related disease. Best Pract Res Clin Obstet Gynaecol. 2018; 47:14-26. https://doi.org/10.1016/j. bpobgyn.2017.08.006.

14. Satterwhite CL, Torrone E, Meites E, Dunne EF, Mahajan R, Ocfemia MC, Su J, Xu F, Weinstock H. Sexually transmitted infections among US women and men: prevalence and incidence estimates, 2008. Sex Transm Dis. 2013; 40: 18793. https://doi.org/10.1097/OLQ.0b013e318286bb53.

15. Schiller JT, Castellsague X, Garland SM. A review of clinical trials of human papillomavirus prophylactic vaccines. Vaccine. 2012; 30:F123-38. https://doi. org/10.1016/j.vaccine.2012.04.108.

16. Kirnbauer R, Taub J, Greenstone H, Roden R, Durst M, Gissmann L, Lowy DR, Schiller JT. Efficient self-assembly of human papillomavirus type $16 \mathrm{~L} 1$ and L1-L2 into viruslike particles. J Virol. 1993; 67: 6929-36.

17. The announcement by the GAVI Alliance Board to support human papillomavirus (HPV) vaccines in the world's poorest countries. Vaccine. 2012; 30:xii. https://doi. org/10.1016/s0264-410x(12)01440-5.

18. Levin A, Wang SA, Levin C, Tsu V, Hutubessy R. Costs of introducing and delivering HPV vaccines in low and lower middle income countries: inputs for GAVI policy on introduction grant support to countries. PLoS One. 2014; 9: e101114. https://doi.org/10.1371/journal.pone.0101114. 
19. Kusma B, Scutaru C, Quarcoo D, Welte T, Fischer TC, Groneberg-Kloft B. Tobacco control: visualisation of research activity using density-equalizing mapping and scientometric benchmarking procedures. Int J Environ Res Public Health. 2009; 6: 1856-69. https://doi.org/10.3390/ ijerph6061856.

20. Say L, Chou D, Gemmill A, Tuncalp O, Moller AB, Daniels J, Gulmezoglu AM, Temmerman M, Alkema L. Global causes of maternal death: a WHO systematic analysis. Lancet Glob Health. 2014; 2: e323-33. https://doi. org/10.1016/s2214-109x(14)70227-x.

21. Bruni L, Diaz M, Castellsague X, Ferrer E, Bosch FX, de Sanjose S. Cervical human papillomavirus prevalence in 5 continents: meta-analysis of 1 million women with normal cytological findings. J Infect Dis. 2010; 202: 1789-99. https://doi.org/10.1086/657321.

22. Bosch FX, Broker TR, Forman D, Moscicki AB, Gillison ML, Doorbar J, Stern PL, Stanley M, Arbyn M, Poljak M, Cuzick J, Castle PE, Schiller JT, et al, and Authors of the ICO Monograph 'Comprehensive Control of HPV Infections and Related Diseases' Vaccine Volume 30, Supplement 5, 2012. Comprehensive control of human papillomavirus infections and related diseases. Vaccine. 2013; 31:I1-31. https://doi.org/10.1016/j.vaccine.2013.07.026.

23. Forman D, de Martel C, Lacey CJ, Soerjomataram I, LortetTieulent J, Bruni L, Vignat J, Ferlay J, Bray F, Plummer M, Franceschi S. Global burden of human papillomavirus and related diseases. Vaccine. 2012; 30:F12-23. https://doi. org/10.1016/j.vaccine.2012.07.055.

24. Franceschi S, Herrero R, Clifford GM, Snijders PJ, Arslan A, Anh PT, Bosch FX, Ferreccio C, Hieu NT, LazcanoPonce E, Matos E, Molano M, Qiao YL, et al. Variations in the age-specific curves of human papillomavirus prevalence in women worldwide. Int J Cancer. 2006; 119: 2677-84. https://doi.org/10.1002/ijc.22241.

25. Suba EJ, Donnelly AD, Furia LM, Huynh ML, Raab SS. Coming to terms with Vietnam: the Viet/American Cervical Cancer Prevention Project. Diagn Cytopathol. 2005; 33: 344-51. https://doi.org/10.1002/dc.20284.

26. Agosti JM, Goldie SJ. Introducing HPV vaccine in developing countries--key challenges and issues. N Engl J Med. 2007; 356: 1908-10. https://doi.org/10.1056/ NEJMp078053.

27. Wawer MJ, Tobian AA, Kigozi G, Kong X, Gravitt PE, Serwadda D, Nalugoda F, Makumbi F, Ssempiija V, Sewankambo N, Watya S, Eaton KP, Oliver AE, et al. Effect of circumcision of HIV-negative men on transmission of human papillomavirus to HIV-negative women: a randomised trial in Rakai, Uganda. Lancet. 2011; 377: 20918. https://doi.org/10.1016/s0140-6736(10)61967-8.

28. Suba EJ, Raab SS. Lessons learned from successful Papanicolaou cytology cervical cancer prevention in the Socialist Republic of Vietnam. Diagn Cytopathol. 2012; 40: 355-66. https://doi.org/10.1002/dc.21655.
29. Tobian AA, Kong X, Wawer MJ, Kigozi G, Gravitt PE, Serwadda D, Eaton KP, Nalugoda F, Quinn TC, Gray $\mathrm{RH}$. Circumcision of HIV-infected men and transmission of human papillomavirus to female partners: analyses of data from a randomised trial in Rakai, Uganda. Lancet Infect Dis. 2011; 11: 604-12. https://doi.org/10.1016/ s1473-3099(11)70038-x.

30. Castellsague X, Diaz M, Vaccarella S, de Sanjose S, Munoz N, Herrero R, Franceschi S, Meijer CJ, Bosch FX. Intrauterine device use, cervical infection with human papillomavirus, and risk of cervical cancer: a pooled analysis of 26 epidemiological studies. Lancet Oncol. 2011; 12: 1023-31. https://doi.org/10.1016/ s1470-2045(11)70223-6.

31. Vaccarella S, Lortet-Tieulent J, Plummer M, Franceschi $\mathrm{S}$, Bray F. Worldwide trends in cervical cancer incidence: impact of screening against changes in disease risk factors. Eur J Cancer. 2013; 49: 3262-73. https://doi.org/10.1016/j. ejca.2013.04.024.

32. Suba EJ. US-funded measurements of cervical cancer death rates in India: scientific and ethical concerns. Indian J Med Ethics. 2014; 11: 167-75. https://doi.org/10.20529/ ijme.2014.046.

33. Muhwezi WW, Banura C, Turiho AK, Mirembe F. Parents' knowledge, risk perception and willingness to allow young males to receive human papillomavirus (HPV) vaccines in Uganda. PLoS One. 2014; 9: e106686. https://doi. org/10.1371/journal.pone.0106686.

34. Lehtinen M, Apter D, Baussano I, Eriksson T, Natunen K, Paavonen J, Vanska S, Bi D, David MP, Datta S, Struyf F, Jenkins D, Pukkala E, et al. Characteristics of a clusterrandomized phase IV human papillomavirus vaccination effectiveness trial. Vaccine. 2015; 33: 1284-90. https://doi. org/10.1016/j.vaccine.2014.12.019.

35. Sankaranarayanan R, Prabhu PR, Pawlita M, Gheit T, Bhatla N, Muwonge R, Nene BM, Esmy PO, Joshi S, Poli UR, Jivarajani P, Verma Y, Zomawia E, et al. Immunogenicity and HPV infection after one, two, and three doses of quadrivalent HPV vaccine in girls in India: a multicentre prospective cohort study. Lancet Oncol. 2016; 17: 67-77. https://doi.org/10.1016/s1470-2045(15)00414-3.

36. Lehtinen M, Soderlund-Strand A, Vanska S, Luostarinen T, Eriksson T, Natunen K, Apter D, Baussano I, Harjula K, Hokkanen M, Kuortti M, Palmroth J, Petaja T, et al. Impact of gender-neutral or girls-only vaccination against human papillomavirus-Results of a community-randomized clinical trial (I). Int J Cancer. 2018; 142:949-58. https://doi. org/10.1002/ijc.31119.

37. Campos NG, Tsu V, Jeronimo J, Mvundura M, Kim JJ. Estimating the value of point-of-care HPV testing in three low- and middle-income countries: a modeling study. BMC Cancer. 2017; 17: 791. https://doi.org/10.1186/ s12885-017-3786-3.

38. Al-Mutawakel K, Scutaru C, Shami A, Sakr M, Groneberg DA, Quarcoo D. Scientometric analysis of the world-wide 
research efforts concerning Leishmaniasis. Parasit Vectors. 2010; 3: 14. https://doi.org/10.1186/1756-3305-3-14.

39. Rusthoven CG, Koshy M, Sher DJ, Ney DE, Gaspar LE, Jones BL, Karam SD, Amini A, Ormond DR, Youssef AS, Kavanagh BD. Combined-Modality Therapy With Radiation and Chemotherapy for Elderly Patients With Glioblastoma in the Temozolomide Era: A National Cancer Database Analysis. JAMA Neurol. 2016; 73: 821-8. https:// doi.org/10.1001/jamaneurol.2016.0839.

40. Groneberg DA, Weber E, Gerber A, Fischer A, Klingelhoefer D, Brueggmann D. Density equalizing mapping of the global tuberculosis research architecture. Tuberculosis (Edinb). 2015; 95: 515-22. https://doi. org/10.1016/j.tube.2015.05.003.

41. Fricke R, Uibel S, Klingelhoefer D, Groneberg DA. Influenza: a scientometric and density-equalizing analysis. BMC Infect Dis. 2013; 13: 454. https://doi. org/10.1186/1471-2334-13-454.

42. Pleger N, Kloft B, Quarcoo D, Zitnik S, Mache S, Klingelhoefer D, Groneberg DA. Bacterial meningitis: a density-equalizing mapping analysis of the global research architecture. Int J Environ Res Public Health. 2014; 11: 10202-14. https://doi.org/10.3390/ijerph111010202.

43. Schmidt S, Bundschuh M, Scutaru C, Klingelhoefer D, Groneberg DA, Gerber A. Hepatitis B: global scientific development from a critical point of view. J Viral Hepat. 2014; 21:786-93. https://doi.org/10.1111/jvh.12205.

44. Groneberg-Kloft B, Quarcoo D, Scutaru C. Quality and quantity indices in science: use of visualization tools. EMBO Rep. 2009; 10: 800-3. https://doi.org/10.1038/ embor.2009.162.

45. Groneberg-Kloft B, Fischer TC, Quarcoo D, Scutaru C. New quality and quantity indices in science (NewQIS): the study protocol of an international project. J Occup Med Toxicol. 2009; 4: 16. https://doi.org/10.1186/1745-6673-4-16.

46. Lawson McLean AC, Lawson McLean A, Kalff R, Walter J. Google Search Queries About Neurosurgical Topics: Are They a Suitable Guide for Neurosurgeons? World
Neurosurg. 2016; 90: 179-85. https://doi.org/10.1016/j. wneu.2016.02.045.

47. Gerber A, Klingelhoefer D, Groneberg DA, Bundschuh M. Silicosis: geographic changes in research: an analysis employing density-equalizing mapping. J Occup Med Toxicol. 2014; 9: 2. https://doi.org/10.1186/1745-6673-9-2.

48. Gerber A, Groneberg DA, Klingelhofer D, Bundschuh M. Gout: a critical analysis of scientific development. Rheumatol Int. 2013; 33: 2743-50. https://doi.org/10.1007/ s00296-013-2805-1.

49. Hirsch JE. An index to quantify an individual's scientific research output. Proc Natl Acad Sci U S A. 2005; 102: 16569-72. https://doi.org/10.1073/pnas.0507655102.

50. Bundschuh $\mathrm{M}$, Groneberg DA, Klingelhoefer D, Gerber A. Yellow fever disease: density equalizing mapping and gender analysis of international research output. Parasit Vectors. 2013; 6: 331. https://doi. org/10.1186/1756-3305-6-331.

51. Gastner MT, Newman ME. Diffusion-based method for producing density-equalizing maps. Proc Natl Acad Sci U S A. 2004; 101: 7499-504. https://doi.org/10.1073/ pnas.0400280101.

52. GeoVista, GeoVizToolkit, URL: https://www.geovista.psu. edu/geoviztoolkit/ (accessed Nov 2016).

53. The World Bank, Data, World Bank Country and Lending Groups, URL: https://datahelpdesk.worldbank.org/ knowledgebase/articles/906519 (accessed Nov 2016).

54. Carl J, Schwarzer M, Klingelhoefer D, Ohlendorf D, Groneberg DA. Curare--a curative poison: a scientometric analysis. PLoS One. 2014; 9: e112026. https://doi. org/10.1371/journal.pone.0112026.

55. Mund M, Kloft B, Bundschuh M, Klingelhoefer D, Groneberg DA, Gerber A. Global research on smoking and pregnancy-a scientometric and gender analysis. Int $\mathrm{J}$ Environ Res Public Health. 2014; 11: 5792-806. https://doi. org/10.3390/ijerph110605792. 